\title{
The Affect of Social Media Marketing and Consumer Engagement on Disney plus Hotstar Consumer Buying Intentions in Indonesia (Study on Youtube and Instagram)
}

\author{
Natasya Dea Novitarizki Darmawan ${ }^{\# 1}$, Indira Rachmawati ${ }^{\# 2}$, Ratih Hendayani ${ }^{\# 3}$

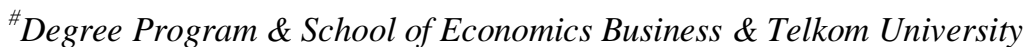 \\ Telekomunikasi St. No. 1, Terusan Buahbatu - Bojongsoang, Sukapura, SubDist. Dayeuhkolot, Bandung, West \\ 40257, Indonesia
}

\begin{abstract}
The entertainment industry has just launched Disney Plus Hotstar in early September 2020 and started its marketing on social media Youtube and Instagram. This study aims to determine the effect of social media marketing Youtube and Instagram on the purchase intention of Disney Plus Hotstar consumers, the influence of YouTube and Instagram social media marketing on Disney Plus Hotstar consumer engagement, and to see the effect of consumer engagement on the purchase intention of Disney Plus Hotstar customers by spreading questionnaire to 400 respondents using social media sites Youtube and Instagram in Indonesia. The hypothesis was tested using a structural equation model which was developed following the existing literature review. The results show that social media marketing has a significant relationship with consumer purchase intentions, where consumer engagement acts as a mediating variable in influencing social media users to obtain consumer purchase intentions. The study confirms that marketers must respond to the importance of increasing the use of social media because it has a strong influence on consumer's purchase intentions. Managerial advice that can be applied by companies is to always monitor consumer engagement by adjusting the company's social media marketing strategy.
\end{abstract}

Keywords — Social Media Marketing, Consumer Engagement, Purchase Intention.

\section{INTRODUCTION}

Internet users in Indonesia increased when the government imposed PSBB (Large-Scale Social Restrictions) in March 2020 and PPKM (Implementation of Community Activity Restrictions) in July 2021 due to the Covid19 pandemic that occurred in Indonesia so that people were asked to stay at home and communicate online to decide viral chain. It was recorded in the data report from we are social that the increase in internet users from 2020 to 2021 was $6.3 \%$, around 10 million. This increase also applies to the increasing number of Youtube and Instagram social media users. Information from the report in 2021, Youtube users will reach 107 million and Instagram users will reach 85 million.[3]

Disney Plus Hotstar as a paid viewing service provider application that was just inaugurated in Indonesia in September 2020 then utilizes the two social media to market its services and compete with several other applications, namely Netflix, Iflix, and Viu. Digital advances made internet users increase and the occurrence of the Covid-19 pandemic in the world at the beginning of 2020 strengthened this so that people had to stay home and enjoy online entertainment because many were still afraid to watch movies live in theatres and refrained from going to the cinema and choose to enjoy the entertainment of watching movies from home to avoid the chain of spreading the virus from getting wider. Starting from this problem, many SVOD platforms then competed to become an alternative to entertainment from home and as a solution to watching movies legally to replace cinemas, one of which was Disney Plus Hotstar which was just launched on September 5, 2020. Since it was officially launched, the number of subscriptions has been growing until the following year. Based on Rudyanto's research (2018), social media marketing has a significant effect on purchase intentions and consumer involvement so that social media can be used as marketing tools to increase consumers' purchase intentions. 
DOI: $\underline{10.51386 / 25815946 / \mathrm{ijsms}-\mathrm{v} 4 \mathrm{i} 4 \mathrm{p} 123}$

For this reason, the researcher wants to prove whether the results of the study apply to Disney Plus Hotstar marketing on the two social media platforms, namely Youtube and Instagram, then to prove that the involvement of Disney Plus Hotstar consumers on Youtube and Instagram affects the purchase intention of Disney Plus Hotstar consumers. formulated in this study are:

1. Is there any influence of Youtube and Instagram Social Media Marketing on Disney Plus Hotstar Consumer Engagement?

2. Is there any influence of Youtube and Instagram Social Media Marketing on Disney Plus Hotstar customers' Purchase Intention?

3. Is there any influence of Consumer Engagement on Disney Plus Hotstar Consumer Purchase Intention?

\section{THEORETICAL REVIEW}

\section{A. Social Media}

According to Nasrullah (2016), the development of individual relationships with media devices can show social media. Social Media is a medium on the internet that provides opportunities for users to introduce themselves, interact, collaborate, share, exchange ideas and opinions, and communicate with other users as well as form social bonds through cyberspace or in networks. Van Dijk, in Nasrullah (2016) argues that social media is a means that focuses on the existence of users that makes it easier for them to do activities and collaborate, therefore social media can be seen as an online intermediary that strengthens relationships between users as well as a social bond.[10]

\section{B. Marketing Communication}

Kotler \& Keller (2009) argue that marketing communication is a means that can be used by companies to inform, persuade, and remind consumers directly or indirectly about a product and brand. Marketing communications are very useful for extending a company's brand image to many people, places, events, experiences, feelings, and other things. They can contribute to brand equity, by embedding brands in memory and creating their image, as well as driving sales, and even influencing stock values.[5] There is also Sutisna (2002) who explains that marketing communication plays a very big role for marketers because communication exists to inform consumers to the wider community that a product has been marketed. Determination of communication targets will greatly determine the success of communication because by determining the right targets, the communication process will run effectively and efficiently. [14]

Marketing communication is a tool used by companies to inform, persuade, and remind consumers both directly and indirectly about the products and brands they offer (Kotler \& Keller, 2016).[6]

According to Kotler in Surniandari (2017), marketing communication is a medium used by companies in their efforts to inform, persuade, and remind consumers directly or indirectly about the products or services offered.[13]

\section{Digital Marketing}

According to Kotler et al. (2017), the mixing of digital marketing does not need to replace traditional marketing because the two certainly complement each other. As the interaction progresses and the customer demands a closer relationship with the digital marketing company it becomes more important. The most important role of digital marketing is to drive action and engage. Since digital marketing is more responsible than traditional marketing, the focus is on encouraging whereas traditional marketing is on initiating the interaction with the customer.[7]

Kotler \& Armstrong (2018) describes in their book entitled Principles of Marketing, the success of the technology company Samsung in its marketing strategy using social media which allows its customers and brand ambassadors to socially network with others by fostering an environment of advocacy and a true celebration of its products and services. In addition, Samsung engages customers globally directly through key influencers and opinion leaders. Much of Samsung's social media success has been to create awareness and stir up rumours about a new device to be launched. Samsung invites a group of influential Bloggers, Twitterati, and socially active Youtubers for a sneak peek before the launch of any new flagship device. This event usually generates thousands of mentions on social media that generate awareness and preference about this new device, one example being the launch of the Samsung Galaxy Note 5 in New York in 2015.[8] 
DOI: $\underline{10.51386 / 25815946 / \mathrm{ijsms}-\mathrm{v} 4 \mathrm{i} 4 \mathrm{p} 123}$

\section{Consumer Engagement}

Consumer engagement requires active interaction between the customer and the brand and provides satisfaction with the valuable experience and functionality of a product and service. Consumer engagement is considered a strategy that marketers need for the purpose of maintaining competitive power with competitors. (Sedley \& Perks, 2008 in Rudyanto, 2018).[12]

Bowden in Thakur (2016) states that customer engagement is a psychological stage that triggers customer loyalty). In addition, Bowden in Hapsari et al., (2017). stated that customer engagement can be seen as a kind of behavior that comes from rational and emotions that play a role in maintaining customer loyalty to company services. So et al. in Hapsari et al. (2017) stated that customer engagement significantly affects the customer's intention to recommend the brand.

\section{III.RESEARCH METHOD}

\section{A. Data Collection Techniques}

This research was conducted on Youtube and Instagram social media users in Indonesia who have never subscribed to Disney Plus Hotstar. The data in this study were obtained from the results of filling out questionnaires and the data sources were obtained from Youtube and Instagram social media users in Indonesia who have never subscribed to Disney Plus Hotstar. The questionnaire is considered valid if the statements in the questionnaire are answered entirely and, in each statement, there is only one answer. The following are the details of distributing the questionnaire:

\section{TABLE I DETAILS OF DISTRIBUTION OF RESEARCH QUESTIONNAIRES}

\begin{tabular}{|c|c|}
\hline Questionnaire Classification & Total \\
\hline Number of questionnaires distributed & 400 \\
\hline Number of returned questionnaires & 400 \\
\hline Number of valid questionnaires & 400 \\
\hline
\end{tabular}

Based on the table above, it was found that the number of questionnaires distributed was 400 questionnaires, the number of questionnaires returned was 400 questionnaires. Of the number of questionnaires that were returned, then checked and the results of the valid questionnaires were 400 respondents who were then used as primary data.

\section{B. Data Analysis Techniques}

Analysis of the data in this study using Structural Equation Modelling (SEM) with Smart PLS (Partial Least Square) software. Where PLS there are 2 models, namely the outer model and the inner model. The outer model is often also called (outer relation or measurement model) specifying the relationship between the variables studied and their indicators. Meanwhile, the inner model is used to evaluate the relationship between potential structures.

\section{Measurement Model (Outer Model)}

The measurement model is a model that connects the latent variable (indirect) with the manifest variable (direct). Based on the SmartPLS estimation method, the path diagram for the measurement model is obtained below:

Fig. 1 Path Diagram of Model Measurement

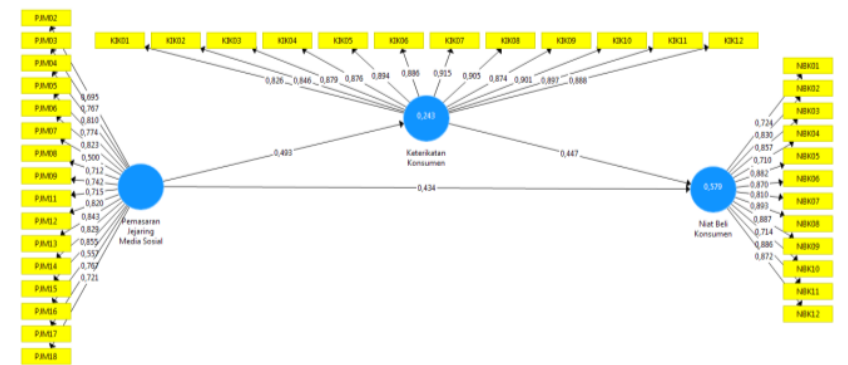

Through the path diagram above, the yellow box shows each indicator, and the blue circle is an indirect variable. On each arrow, there is a number, namely the value of the validity of each indicator, and test the 
DOI: $\underline{10.51386 / 25815946 / \mathrm{ijsms}-\mathrm{v} 4 \mathrm{i} 4 \mathrm{p} 123}$

Volume: 4 Issue: 4

July to August 2021

https://www.ijjsmsjournal.org

reliability of the structure of the variables studied. An indicator can be said to be valid if it has a factor weight greater than 0.5 . The following are the measurement models involved in this study:

\section{Convergent Validity}

Convergent validity is a proven validity of the scores obtained by instruments that assess concepts or calculate concepts with different methods that have a high correlation. The correlation between the indicator scores and the variable scores becomes a measurement of the convergent validity of the measurement model. The indicator is declared valid if the AVE (Average Variance Extracted) value is above 0.5 so that it can be said that the measurement has met the criteria for convergent validity. The following are the results of testing using the Smart PLS software:

\begin{tabular}{|l|c|c|c|}
\hline \multicolumn{1}{|c|}{ Variable } & AVE & $\begin{array}{c}\text { Critical } \\
\text { Value }\end{array}$ & $\begin{array}{c}\text { Evaluation } \\
\text { Model }\end{array}$ \\
\hline Social Media Marketing (X) & 0,565 & & Valid \\
\hline Consumer Engagement (Z) & 0,779 & \multirow{2}{*}{$>0,5$} & Valid \\
\cline { 1 - 2 } Consumer Purchase Intention (Y) & 0,690 & & Valid \\
\hline
\end{tabular}

Table II shows that the three variables have an AVE value that is greater than the critical value of 0.5 . Thus, it can be concluded that the convergent validity conditions for all variables have been met.

\section{Discriminant Validity}

Discriminant Validity can be seen through the measurement of cross-loading factor by comparing the AVE and the correlation between variables in a study. If the data shows the correlation construct of each indicator has a value greater than the value of the other constructs, then the variable has a high cross-loading factor. The following is the result of the cross-loading factor using SmartPLS:

TABle III Discriminant VAlidity (Cross LoAding FACTOR) Result

\begin{tabular}{|c|c|c|c|}
\hline Indicator & $\begin{array}{c}\text { Social Media } \\
\text { Marketing }(\mathbf{X})\end{array}$ & $\begin{array}{l}\text { Consumer } \\
\text { Behavior }(\mathbf{Z})\end{array}$ & $\begin{array}{c}\text { Consumer } \\
\text { Purchase } \\
\text { Intention (Y) }\end{array}$ \\
\hline PJM01 & 0,695 & 0,216 & 0,441 \\
\hline PJM02 & 0,767 & 0,361 & 0,523 \\
\hline PJM03 & 0,810 & 0,404 & 0,541 \\
\hline PJM04 & 0,774 & 0,383 & 0,551 \\
\hline PJM05 & 0,823 & 0,401 & 0,535 \\
\hline PJM06 & 0,500 & 0,161 & 0,287 \\
\hline PJM07 & 0,712 & 0,398 & 0,468 \\
\hline PJM08 & 0,742 & 0,405 & 0,507 \\
\hline PJM09 & 0,715 & 0,302 & 0,422 \\
\hline PJM10 & 0,820 & 0,404 & 0,487 \\
\hline PJM11 & 0,843 & 0,445 & 0,547 \\
\hline PJM12 & 0,829 & 0,423 & 0,551 \\
\hline PJM13 & 0,855 & 0,484 & 0,580 \\
\hline PJM14 & 0,557 & 0,190 & 0,316 \\
\hline PJM15 & 0,767 & 0,375 & 0,504 \\
\hline PJM16 & 0,721 & 0,399 & 0,481 \\
\hline KIK01 & 0,479 & 0,826 & 0,592 \\
\hline KIK02 & 0,416 & 0,846 & 0,573 \\
\hline KIK03 & 0,403 & 0,879 & 0,579 \\
\hline KIK04 & 0,434 & 0,874 & 0,584 \\
\hline KIK05 & 0,376 & 0,894 & 0,540 \\
\hline KIK06 & 0,473 & 0,886 & 0,606 \\
\hline KIK07 & 0,456 & 0,915 & 0,604 \\
\hline KIK08 & 0,447 & 0,905 & 0,578 \\
\hline KIK09 & 0,427 & 0,874 & 0,566 \\
\hline KIK10 & 0,427 & 0,901 & 0,584 \\
\hline KIK11 & 0,403 & 0,897 & 0,559 \\
\hline KIK12 & 0,460 & 0,888 & 0,615 \\
\hline NBK01 & 0,565 & 0,480 & 0,724 \\
\hline NBK02 & 0,562 & 0,539 & 0,830 \\
\hline NBK03 & 0,573 & 0,602 & 0,857 \\
\hline NBK04 & 0,452 & 0,437 & 0,710 \\
\hline NBK05 & 0,545 & 0,599 & 0,882 \\
\hline NBK06 & 0,543 & 0,593 & 0,870 \\
\hline
\end{tabular}


DOI: $\underline{10.51386 / 25815946 / \mathrm{ijsms}-\mathrm{v} 4 \mathrm{i} 4 \mathrm{p} 123}$

\begin{tabular}{|c|c|c|c|}
\hline Indicator & $\begin{array}{c}\text { Social Media } \\
\text { Marketing (X) }\end{array}$ & $\begin{array}{c}\text { Consumer } \\
\text { Behavior (Z) }\end{array}$ & $\begin{array}{c}\text { Consumer } \\
\text { Purchase } \\
\text { Intention (Y) }\end{array}$ \\
\hline NBK07 & 0,586 & 0,483 & 0,810 \\
\hline NBK08 & 0,607 & 0,578 & 0,893 \\
\hline NBK09 & 0,540 & 0,589 & 0,887 \\
\hline NBK10 & 0,439 & 0,440 & 0,714 \\
\hline NBK11 & 0,565 & 0,600 & 0,886 \\
\hline NBK12 & 0,523 & 0,603 & 0,872 \\
\hline
\end{tabular}

Based on Table 4.6, it can be concluded that all constructs in the estimated model have met the discriminant validity criteria. The condition is that the square root value of the AVE of each construct is greater than the correlation value between the constructs, so it can be said that the indicators used in this study have met the requirements.

\section{Analysis of Research Results and Discussion}

Kotler et al. (2017) explain that the most important role of digital marketing is to drive action and engage. Because digital marketing is more responsible than traditional marketing, the focus is on encouraging while traditional marketing is on initiating interactions with customers, while Thakur (2016) explains that customer engagement is a psychological atmosphere that occurs according to customer experience and is related to the central object. The two independent variables show the Social Media Marketing associated by Disney Plus Hotstar Consumer Engagement to trigger its Users to intend to purchase Disney Plus Hotstar services so it can be said that Social Media Marketing and Engagement affect Disney Plus Hotstar Consumer Purchase Intention.

\section{A. Social Media Marketing Variable (X)}

Based on the respondent's responses, overall, it is included in the category of Fairly Good. It is shown by the total score obtained by the Social Media Marketing variable, which is $71.38 \%$. Among the 16 statements regarding the Social Media Marketing variable, the statement that received the highest score was "The YouTube social media provides an opportunity for me to share information with other parties about Disney Plus Hotstar" with a percentage of $82.13 \%$ and is included in the good category. This shows that Respondents can share information with other parties about Disney Plus Hotstar on the social media Youtube. Meanwhile, even though it is still in the Fairly Good category, the statement that received the lowest score was "I am satisfied with the marketing of Disney Plus Hostar's social media on the Instagram social media, which is $67.04 \%$. This shows that Instagram's social media marketing makes respondents feel satisfied.

\section{B. Consumer Engagement Variable (Z)}

Based on the respondent's response, overall, it is included in the category of Less Good. It is shown by the total score obtained by the Consumer Engagement variable, which is $47.30 \%$. Among the 12 statements regarding the Consumer Engagement variable, the statement that got the highest score was "I often visit the Youtube social media page related to Disney Plus Hostar" with a percentage of $50.4 \%$ and is included in the Less Good category. This shows that the Disney Plus Hotstar YouTube social media page is rarely visited by respondents. While even though it is still in the Poor category, the statement that gets the lowest score is "I often comment on the Instagram social media about Disney Plus Hotstar," which is $43.54 \%$. This shows that not many respondents commented on Disney Plus Hotstar on the Instagram social media.

\section{Consumer Purchase Intention Variable (Y)}

Based on the respondent's responses, overall, it is included in the category of Fairly Good. It is shown by the total score obtained by the Consumer Purchase Intention variable, which is $63.79 \%$. Among the 12 statements regarding the Consumer Purchase Intention variable, the statement that got the highest score was "I am very likely to buy Disney Plus Hotstar services recommended by my friends on the Instagram social media that I follow" with a percentage of $66.92 \%$ and included in the category of Good Enough. This shows that respondents are very likely to buy Disney Plus Hotstar services recommended by friends on the Instagram social media they follow. Meanwhile, although still in the Good Enough category, the statement that received the lowest score was "I am interested in buying Disney Plus Hostar services which are marketed on the Instagram social media that I follow," which is $60.08 \%$. This shows that quite a lot of respondents are interested in buying Disney Plus Hotstar services, which are followed on the Instagram social media. 
DOI: $\underline{10.51386 / 25815946 / \mathrm{ijsms}-\mathrm{v} 4 \mathrm{i} 4 \mathrm{p} 123}$

\section{Social Media Marketing on Consumer Engagement}

Meanwhile, the Social Media Marketing variable $(X)$ has a $t_{\text {count }}$ value that is greater than the $t_{\text {table }}$ value $(13.794>1.96)$ and a significance value that is smaller than the level of accuracy $(0.000<0.05)$, then $\mathrm{H} 0$ is rejected. Thus, it can be concluded that there is a significant influence of Social Media Marketing (X) on Consumer Engagement (Z).

This is in accordance with Rudyanto's research (2018) which shows that social media provides an interactive online means of communication so that it can influence word-of-mouth, which distinguishes it from traditional marketing methods.

\section{E. Consumer Engagement to Consumer Purchase Intention}

Consumer Engagement Variable $(Z)$ has a $t_{\text {count }}$ value that is greater than the $t_{\text {table value }(10.579>1.96) \text { and a }}$ significance value that is smaller than the level of accuracy $(0.000<0.05)$, then $\mathrm{H} 0$ is rejected. Thus, it can be concluded that there is a significant effect of Consumer Engagement $(\mathrm{Z})$ on Consumer Purchase Intention $(\mathrm{Y})$.

This finding is in line with the findings of Rudyanto (2018) which states that consumer involvement is positive on consumer purchase intentions and is in accordance with Husnain et al., (2017) which states that engaged consumers are accompanied by intentions to build closer involvement with the brand and are also in line with the results. from the research of Rini, et al. (2017) which states that knowledge and environmental awareness have a positive and significant effect on consumers' purchase intentions.

\section{F. Social Media Marketing on Consumer Purchase Intention}

The Social Media Marketing Variable $(X)$ has a $t_{\text {count }}$ value that is greater than the $t_{\text {table }}$ value $(9.056>1.96)$ and a significance value that is smaller than the level of accuracy $(0.000<0.05)$, then H0 is rejected. Thus, it can be concluded that there is a significant influence of Social Media Marketing (X) on Consumer Purchase Intention (Y).

This finding is in line with the research by Rionaldy \& Trenggana (2019) which states that social media advertising influences purchasing decisions but is inversely proportional to the research of Dülek \& Aydin (2020) which states that social media marketing has no effect on consumers' purchase intentions.

\section{G. Social Media Marketing on Consumer Purchase Intention through Consumer Engagement}

The Social Media Marketing Variable $(X)$ has a $t_{\text {count }}$ value that is greater than the $t_{\text {table }}$ value $(8.388>1.96)$ and a significance value that is smaller than the level of accuracy $(0.000<0.05)$, so H0 is rejected. Thus, it can be concluded that there is a significant effect of Social Media Marketing (X) on Consumer Purchase Intention (Y) through Consumer Engagement (Z).

This study also found that there is an indirect influence of Social Media Marketing (X) on Consumer Purchase Intention (Y) through Consumer Engagement (Z).

\section{IV.CONCLUSIONS}

\section{Conclusions}

Based on the results of the research and discussion on Social Media Marketing on Disney Plus Hotstar Consumer Purchase Intentions in Indonesia that have been stated in the previous chapter, several conclusions can be drawn that the researcher hopes to be able to provide answers to the problems formulated in this study. Here is the conclusion:

a. The Effect of Social Media Marketing on Consumer Purchase Intention

Referring to the results of the Hypothesis Testing in the Path Coefficients Table, the Social Media Marketing variable $(\mathrm{X})$ has a significant effect on Consumer Purchase Intention (Y).

b. The Effect of Consumer Engagement on Consumer Purchase Intention

Referring to the results of the Hypothesis Test in the Path Coefficients Table, the Consumer Engagement variable (Z) has a significant effect on Consumer Purchase Intention (Y).

c. Effect of Social Media Marketing and Consumer Engagement on Consumer Purchase Intention 
DOI: $\underline{10.51386 / 25815946 / \mathrm{ijsms}-\mathrm{v} 4 \mathrm{i} 4 \mathrm{p} 123}$

Referring to the results of the Hypothesis Testing in the Path Coefficients Table, Social Media Marketing Variables (X) and Consumer Engagement (Z), simultaneously have a significant effect on the Independent Variable, namely Consumer Purchase Intention (Y).

\section{Suggestions}

Based on the conclusions described above, the researcher proposes several suggestions that are expected to be useful for Disney Plus Hotstar as the company and for further researchers.

\section{Suggestions for Companies}

Here are some suggestions that the researcher put forward for the company to consider:

a. Disney Plus Hotstar to pay attention to and improve the variables of Social Media Marketing, Consumer Engagement, and Consumer Purchase Intention which, based on the results of Descriptive Analysis, have been included in the good category so that in the future they can enter the Very Good category. In addition, Disney Plus Hotstar to pay attention to and correct the statements that still get the lowest score:

1) Based on the Social Media Marketing variable, the statement that gets the lowest score is "I am satisfied with Disney Plus Hostar's social media marketing on the Instagram social media," The researcher suggests that Disney Plus Hotstar increase its marketing on Instagram social media so that Viewers can easily be satisfied enjoying marketing on the social media Instagram.

2) Based on the Consumer Engagement variable, the statement that got the lowest score was "I often comment on the Instagram social media about Disney Plus Hotstar," The researcher suggests that Disney Plus Hotstar be more active in communicating with its audience on the Instagram social media so that the audience feels valued and exists. considered important and necessary.

3) Based on the Consumer Purchase Intention variable, the statement that gets the lowest score is "I am interested in buying Disney Plus Hostar services which are marketed on the Instagram social media that I follow," The researcher suggests that Disney Plus Hotstar create marketing content that is persuasive and makes the audience curious more about the messages conveyed on the Instagram social media to increase Viewer's interest in purchasing Disney Plus Hotstar services.

b. Disney Plus Hotstar to pay more attention and increase Consumer Engagement because its effect on Consumer Purchase Intention is smaller than the influence of other variables that the researcher uses in this study.

c. Disney Plus Hotstar to pay attention to other factors that are not examined in this study, for example, such as the price factor, to trigger its users to buy Disney Plus Hotstar service packages.

\section{Suggestions for Further Researchers}

This study only examines the Effect of Social Media Marketing on Consumer Purchase Intentions through Consumer Engagement, so the researcher put forward some suggestions for further consideration by the next researcher. Here are the suggestions:

a. Further researchers should conduct research on companies engaged in similar industries-creative industries - so that the results can be used as comparison material.

b. The next researcher is to conduct research on factors other than Social Media Marketing and Consumer Engagement that can affect Consumer Purchase Intentions, for example, such as price, trust, and e-WOM factors, and other marketing strategies.

c. The next researcher is to conduct research that links the variables of Social Media Marketing and Consumer Engagement with variables other than Consumer Purchase Intentions, for example, such as the Brand Awareness variable so that the results can enrich scientific treasures, especially in the field of Marketing Management/Entrepreneurship. 
DOI: $\underline{10.51386 / 25815946 / \mathrm{ijsms}-\mathrm{v} 4 \mathrm{i} 4 \mathrm{p} 123}$

Volume: 4 Issue: 4

July to August 2021

https://www.ijsmsjournal.org

\section{REFERENCES}

[1] Hapsari, R., Clemes, M. D., \& Dean, D., (2017). "The impact of service quality, customer engagement and selected marketing constructs on airline passenger loyalty", International Journal of Quality and Service Sciences, Vol. 9(1), pp. 21-40, doi: http://dx.doi.org/10.1108/IJQSS-07-2016-0048

[2] Hermawan, A. (2014). Komunikasi Pemasaran. Erlangga.

[3] Kemp, S. (2020, July 21). More Than Half of The People On Earth Now Use Social Media. Wearesocial. Retrieved October 20, 2020, from https://wearesocial.com/blog/2020/07/more-than-half-of-the-people-on-earth-now-use-social-media

[4] Kemp, S. (2020, February 18). Digital 2020: Indonesia. Datareportal. Retrieved October 20, 2020, from https://datareportal.com/reports/digital-2020-indonesia

[5] Kotler, P. \& Keller, K. L. (2009). Manajemen Pemasaran (Edisi 13 Jilid satu). Erlangga.

[6] Kotler P. \& Keller, K. L. (2016). Marketing Management 15 (Global Edition). Pearson.

[7] Kotler, P., Kartajaya, H., \& Setiawan, I. (2017). Marketing 4.0: Moving from Traditional to Digital. Willey.

[8] Kotler, P. \& Armstrong, G. (2018). Principles of Marketing (17th ed.). Pearson.

[9] Lam, A. Y. C., Lau, M. M., \& Cheung, R. (2016). Modelling the Relationship among Green Perceived Value, Green Trust, Satisfaction, and Repurchase Intention of Green Products. Contemporary Management Research, 12(1), 47-60. http://doi.org/10.7903/cmr.13842

[10] Nasrullah, R. (2016). Media Sosial: Perspektif Komunikasi, Budaya, Sosioteknologi. Simbiosa Rekatama Media

[11] Rahim, A., Safin, S. Z., Kheng, L. K., Abas, N., \& Ali, S. M. (2016). Factors Influencing Purchasing Intention of Smartphone among University Students. Procidia Economics and Finance, Vol. 37, 245-253. https://doi.org/10.1016/S2212-5671(16)30121-6

[12] Rudyanto. (2018). Pengaruh Pemasaran Jejaring Media Sosial dan Keterkaitan Konsumen Terhadap Niat Beli Konsumen. Jurnal Manajemen dan Pemasaran Jasa, 11(2), 177-200. http://dx.doi.org/10.25105/jmpj.v11i2.3126

[13] Surniandari, A. (2017). Viral Marketing Sebagai Alternatif Strategi Pemasaran Produk Sariz. Jurnal Sekretari dan Manajemen, 1(1), 35-43. https://doi.org/10.31294/widyacipta.v1i1.1480.g1520

[14] Sutisna. (2002). Perilaku Konsumen dan Komunikasi Pemasaran. Remaja Rosdakarya.

[15] Thakur, R. (2016). Understanding Customer Engagement and Loyalty: A Case of Mobile Device for Shopping. Journal of Retailing and Consumer Services, 32, 151-163. https://doi.org/10.1016/j.jretconser.2016.06.004

[16] Toufani, S., Stanton, J. P., dan Chikweche, T. (2017). The Importance of aesthetics on customers' intentions to purchase smartphones Marketing Intelligence \& Planning, Vol. 35 (3), 316-338. https://doi/10.1108/MIP-12-2015-0230 